\title{
META-ANALISIS KEEFEKTIFAN MODEL PEMBELAJARAN STUDENT TEAM ACHIEVEMENT DIVISION (STAD) DALAM MENINGKATKAN HASIL BELAJAR IPS SISWA SD
}

\author{
Moh Rifai, Nyoto Hardjono \\ 292016027@student.uksw.edu
}

Fakultas Keguruan dan Ilmu Pendidikan

Universitas Kristen Satya Wacana, Indonesia

\begin{tabular}{|c|c|}
\hline ARTICLE INFO & ABSTRACT \\
\hline $\begin{array}{l}\text { Submitted: } \\
24 \text { Maret } 2019 \\
24^{\text {th }} \text { March } 2019\end{array}$ & $\begin{array}{l}\text { Abstract: The purpose ofthis research to analize the effectiveness of Student Team Achievement } \\
\text { Division (STAD) model in improving social studies learning of elementary scool students. This model } \\
\text { is one of cooperative learning that can give student learning motivation. First, the researcher } \\
\text { formulated the problem and than collect exiting research data that was already throughgoogle } \\
\text { scholar. The research data found of } 12 \text { articles and } 1 \text { relevantthesis result. The researcher analyzed } \\
\text { the result of the study using quantitative comparison methods. Based on the result of the analysis, } \\
\text { Student Team Achievement Division (STAD) models are effectively used in improving social studies } \\
\text { learning of elementary school students. Increase in students learning of elementary starting from the } \\
\text { lowest } 6.9 \% \text { to the highest } 56.6 \% \text { with an average increase of } 34.61 \% \text {. }\end{array}$ \\
\hline $\begin{array}{l}\text { Accepted: } \\
1 \text { Oktober } 2019\end{array}$ & $\begin{array}{l}\text { Keywords: Student Team Achievement Division (STAD) model, Social Studies Outcomes, Elementary } \\
\text { School }\end{array}$ \\
\hline $\begin{array}{c}1^{\text {th }} \text { October } 2019 \\
\text { Published: } \\
\text { 10 Oktober } 2019 \\
10^{\text {th }} \text { October } 2019\end{array}$ & $\begin{array}{l}\text { Abstrak: Penelitian ini bertujuan untuk menganalisis keefektifan model Student Team Achievement } \\
\text { Division (STAD) dalam meningkatkan hasil belajar IPS siswa SD. Model pembelajaran ini } \\
\text { merupakan salah satu model pembelajaran kooperatif yang dapat memacu motivasi belajar siswa. } \\
\text { Langkah pertama, peneliti merumuskan masalah terlebih dahulu kemudian mengumpulkan data } \\
\text { penelitian yang sudah ada melalui penelusuran google cendikia. Data penelitian yang didapatkan } \\
\text { berupa } 12 \text { artikel dan } 1 \text { hasil skripsi yang paling relevan. Peneliti menganalisis hasil penelitian } \\
\text { dengan menggunakan metode pembanding kuantitatif. Berdasarkan hasil analisis, model } \\
\text { pembelajaran Student Team Achievement Division (STAD) efektif digunakan dalam meningkatkan } \\
\text { hasil belajar IPS siswa SD. Peningkatan hasil belajar IPS siswa SD mulai dari yang terendah } 6.9 \% \\
\text { sampai yang tertinggi } 56.6 \% \text { dengan rata-rata peningkatan sebesar } 34.01 \% \text {. }\end{array}$ \\
\hline & Kata Kunci: Model Student Team Achievement Division (STAD), hasil belajar IPS, sekolah dasar \\
\hline CITATION & $\begin{array}{l}\text { Rifai, M., \& Hardjono, N. (2019). Meta-Analisis Keefektifan Model Pembelajaran Student Team } \\
\text { Achievement Division (STAD) dalam Meningkatkan Hasil Belajar IPS Siswa SD. Primary: } \\
\begin{array}{llllll}\text { Jurnal Pendidikan Guru Sekolah } & \text { Dasar, } & 8 & \text { (2), } & \text { 173-179. } & \text { DOI: } \\
\text { http://dx.doi.org/10.33578/jpfkip.v8i2.7119. } & & & \end{array}\end{array}$ \\
\hline
\end{tabular}

\section{PENDAHULUAN}

Kualitas pendidikan sangat berpengaruh terhadap perkembangan dan kemajuan suatu negara. Kualitas pendidikan yang baik tentu akan mencetak generasi bangsa yang baik pula sehingga dapat memajukan sebuah negara. Salah satu upaya untuk meningkatkan mutu pendidikan adalah melaksanakan pembelajaran yang baik. Hal ini sesuai dengan Peraturan Pemerintah RI Nomor 19 tahun 2005 tentang Standar Nasional Pendidikan pada pasal 19 yang menjelaskan bahwa usaha pemerintah untuk meningkatkan mutu pendidikan di Indonesia yaitu pelaksanaan pembelejaran pada satuan pendidikan yang interaktif, inspiratif, menyenangkan, menantang, memotivasi untuk aktif, kreatif, mandiri sesuai bakat, minat dan perkembangan fisik dan psikologis peserta didik. Pembelajaran di indonesia saat ini masih banyak yang belum menerapkan pembelajaran yang aktif, 
kreatif. Seperti halnya yang ditemukan oleh Sumiyati pada tahun 2017 di SD Negeri 05 Kabawetan Kepahiang bahwa dalam proses pembelajaran masih kurang berinteraksi antara guru dan siswa, guru kurang menguasai tentang metode pengajaran, siswa cenderung pasif, metode yang digunakan masih monoton, siswa cenderung hanya menghafal bukan memahami materi pelajaran. Hal yang sama juga ditemukan oleh Wijanarko pada tahun 2017 di SD Muhammadiyah Domban 4 Sleman Yogyakarta, dimana penggunaan model pembelajaran yang kurang tepat dapat menimbulkan kebosanan siswa dalam proses pembelajaran, materi kurang dipahami, dan menjadi pembelajaran yang monoton sehingga siswa kurang motivasi dalam belajar. Jika siswa kurang motivasi belajar akan berpengaruh pada hasil belajar yang rendah. Menurut Warti (2016:184) menyatakan bahwa semakin tinggi motivasi belajar maka makin baik pula hasil belajarnya dan sebaliknya. Jadi, melaksanakan pembelajaran yang variatif sangat diperlukan untuk meningkatkan motivasi belajar siswa. Saat ini kurikukum 2013 yang berlaku di indonesia juga mengacu pada prinsip pembelajaran yang aktif, kreatif dan inovatif. Oleh sebab itu, guru dituntut untuk melaksanakan pembelajaran yang aktif, kreatif dan inovatif dengan menggunakan model pembelajaran yang variatif.

Banyak model pembelajaran yang dapat digunakan oleh guru untuk menciptakan pembelajaran yang lebih baik. Salah satu model pembelajaran yang dapat digunakan adalah model Student Team Achievement Division (STAD). Menurut Gusniar (2014: 199) menyatakan bahwa model pembelajaran Student Team Achievement Division (STAD) merupakan salah satu model pembelajaran kooperatif yang menjadikan siswa

\section{METODE PENELITIAN}

Penelitian ini menggunakan jenis penelitian meta analisis yang melibatkan hasil penelitian dari beberapa peneliti. Hasil penelitian dari beberapa peneliti didapatkan melalui penelusuran google cendikia atau google scholar. Penelusuran menggunakan kata kunci "Student Team Achievement Division", "STAD”, dan "Hasil Belajar IPS". Berdasarkan hasil penelusuran termotivasi untuk belajar sebab tidak ada siswa yang merasa didiskriminasikan, semua siswa bertanggungjawab terhadap skor kelompoknya, serta adanya tutor sebaya antara teman sekelompok. Lebih lanjut menjelaskan bahwa dalam model pembelajaran ini siswa diberi kesempatan untuk melakukan kolaborasi dan elaborasi dengan teman sebaya dalam bentuk diskusi kelompok untuk memecahkan suatu permasalahan. Jadi, siswa dapat melatih memecahkan masalah bersama kelompok namun tetap diberikan tanggungjawab secara individu sehingga semua nggota dapat berperan aktif. Kelompok terdiri dari 4-5 orang yang heterogen (jenis kelamin, suku, kemampuan yang beragam). Dengan demikian, siswa dapat meningkatkan motivasi belajar sehingga hasil belajar akan meningkat terutama dalam pembelajaran IPS. Dimana menurut Rahmad (2016: 73) pembelajaran IPS menjadi salah satu pembelajaran yang penting apa yang menjadi informasi diluar sekolah dapat dikembangkan menjadi sesuatu yang lebih bermakna sesuai dengan jenjang pendidikannya yang belum mampu memahami masalah-masalah yang ada di sekitarnya, melalui pengajaran IPS peserta didik dapat memperoleh pengetahuan, keterampilan, sikap dan kepekaan untuk menghadapi hidup dengan tantangantantangannya. Jadi, jika model pembelajaran Student Team Achievement Division (STAD) menjadi langkah yang tepat untuk mengatasi permasalahan yang dihadapi siswa di sekolah dasar.

Berdasarkan uraian tersebut, fokus penelitian ini adalah untuk menganalisis kembali apakah model pembelajaran Student Team Achievement Division (STAD) efektif dalam meningkatkan hasil belajar IPS siswa SD?

dengan kata kunci tersebut, didapatkan beberapa artikel dari jurnal dan hasil skripsi mahasiswa dari repository. Beberapa artikel dan hasil skripsi dipilih kembali berdasarkan adanya skor sebelum dan sesudah tindakan sehingga diperoleh 12 artikel dan 1 skripsi yang paling sesuai. Teknik analisis data yang digunakan adalah dengan metode pembanding yaitu dengan membandingkan 
skor sebelum dan sesudah tindakan pembelajaran Student Team Achievement Division (STAD), kemudian dicari selisihnya dan dibagi skor sebelum tindakan pembelajaran Student Team

\section{HASIL DAN PEMBAHASAN}

Penelitian ini melibatkan 13 hasil penelitian tentang model Student Team Achievement Division (STAD) dalam pembelajaran IPS. Berikut adalah hasil penelitian yang diikutsertakan dalam penelitian meta analisis ini:

1. Efektivitas Model Pembelajaran Kooperatif Tipe STAD Ditinjau dari Hasil Belajar IPS Siswa Kelas 4 SD oleh Firosalia Kristin pada tahun 2016.

2. Pengaruh Penerapan Model Pembelajaran Kooperatif Tipe STAD Terhadap Peningkatan Prestasi Belajar Mata Pelajaran IPS Pada Siswa Kelas V SD N Karang Duren oleh Oky Wasrik Dwi Nugroho pada tahun 2014.

3. Meningkatkan Prestasi Belajar Siswa dengan Pembelajaran IPS Siswa Kelas IV MIN Manisrejo Kota Madiun oleh Moh. Rifai pada tahun 2014.

4. Pengaruh Model Pembelajaran Student Team Achievement Devision (STAD) dan Mind Mapping terhadap Hasil Belajar Siswa Kelas IV Sekolah Dasar oleh Fakhriyatu Zahro, I Nyoman Sudana Degeng, dan Alif Mudiono.

5. Penerapan Model Pembelajaran Kooperatif Tipe Student Team Achievement Devision (STAD) untuk Meningkatkan Hasil Belajar IPS Siswa Kelas V SD Negeri 35 Pekanbaru oleh Lazim N.

6. Peningkatan Aktivitas dan Hasil Belajar IPS Melalui Pembelajaran Kooperatif Tipe STAD Variasi Permainan Nagawan Pada Siswa Kelas V SD Negeri Perumnas oleh Jatimah.

7. Peningkatan Aktivitas dan Hasil Belajar Siswa dalam Pembelajaran IPS Tipe STAD Kelas V SD oleh Saten.

8. Penerapan Model Pembelajaran Kooperatif Tipe STAD untuk Meningkatkan Hasil Belajar
Achievement Division (STAD) dalam bentuk persen untuk mengetahui pengaruh model Student Team Achievement Division (STAD).

IPS Siswa Kelas IV SD Negeri 008 Talang Perigi Kecamatan Rakit Kulim Kabupaten Indragiri Hulu oleh Helni Dlita, Hendri Marhadi, dan Eddy Noviana.

9. Peningkatan Aktivitas dan Hasil Belajar Melalui Pembelajaran Kooperatif Tipe STAD oleh Yustin Susanti, Wahjoedi dan Sugeng Utaya.

10.Penerapan Model Pembelajaran Kooperatif Tipe STAD Meningkatkan Hasil Belajar Siswa dalam Pembelajaran IPS Kelas IV oleh Rochmatin.

11.Penggunaan Model Pembelajaran Kooperatif Tipe Student Team Achievement Devision (STAD) untuk Meningkatkan Hasil Belajar Siswa Kelas V SDN Kedungrejo, WaruSidoarjo oleh Achmad Syaiful B.

12.Implementation of Cooperative Learning Model Student Team Achievement Division Can Improve Learning Outcomes IPS Third Grade Students of SD Negeri 9 Duri Barat Kecamatan Mandau Tahun Ajaran 2015/2016 oleh Deswita, Hendri Marhadi dan Lazim N.

13.Implementasi Model Pembelajaran Kooperative Tipe Student Team Achievement Divisions dalam Meningkatkan Hasil Belajar IPS Siswa oleh Wina Dwi Puspitasari.

Hasil penelitian dari 13 peneliti harus dianalisis terlebih dahulu dengan mengambil intinya. Inti hasil penelitian yang didapatkan berupa peningkatan hasil belajar IPS siswa dengan menghitung selisih nilai sebelum dan sesudah melaksanakan pembelajaran dengan menggunakan model Student Team Achievement Division (STAD). Berikut ini adalah hasil analisis data berdasarkan hasil penelitian dari ke-13 peneliti: 
Tabel. 1 Hasil Analisis Model Pembelajaran Student Team Achievement Division (STAD)

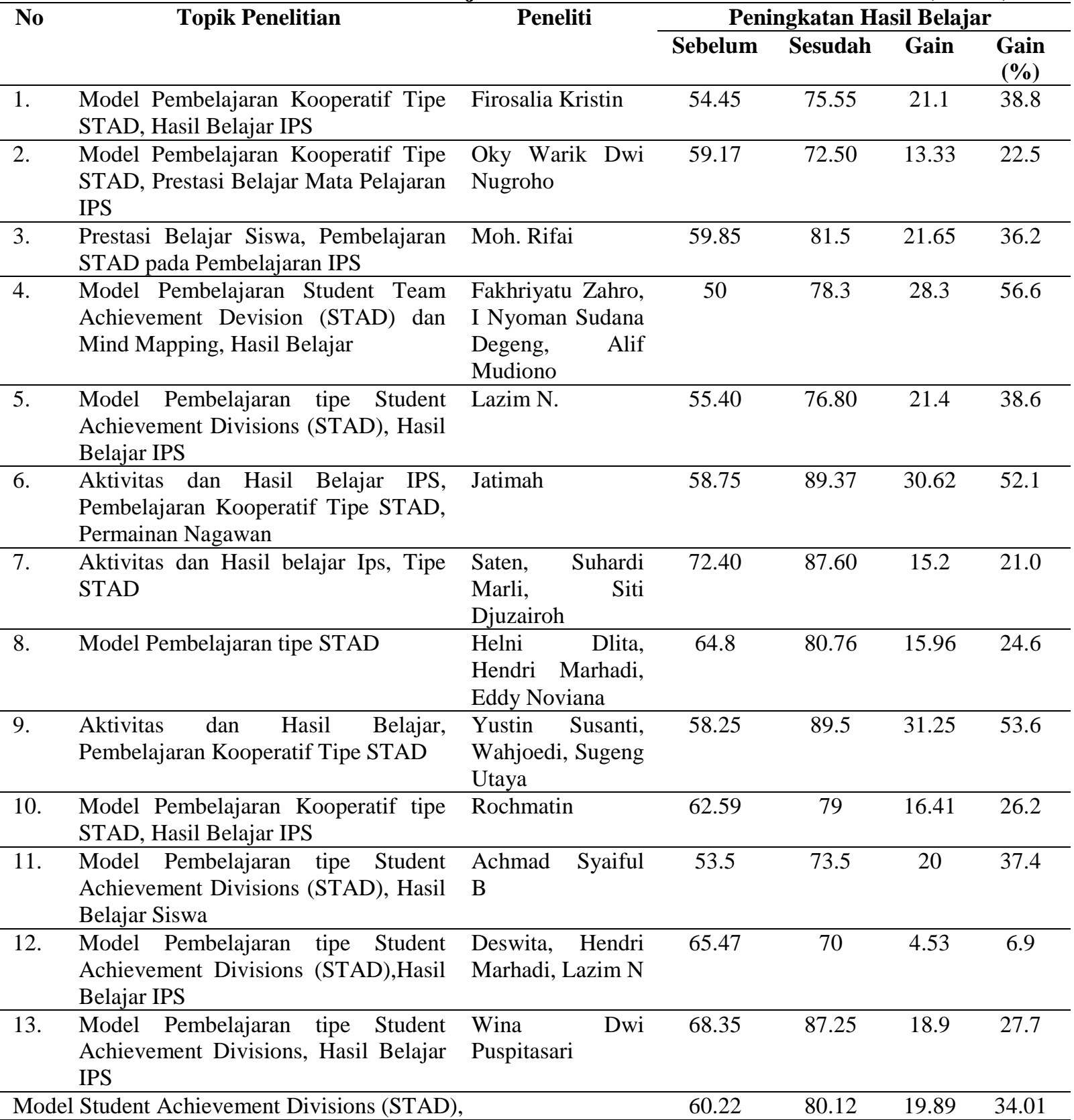

Tabel. 2 Paired Samples Statistics

\begin{tabular}{cccccc}
\hline \multicolumn{5}{c}{ Paired Samples Statistics } \\
\hline & Mean & N & $\begin{array}{c}\text { Std. } \\
\text { Deviation }\end{array}$ & $\begin{array}{c}\text { Std. Error } \\
\text { Mean }\end{array}$ \\
\hline Pair 1 & Sebelum & 60.2292 & 13 & 6.33783 & 1.75780 \\
\cline { 2 - 6 } & Sesudah & 80.1254 & 13 & 6.60445 & 1.83174 \\
\hline
\end{tabular}


DOI : http://dx.doi.org/10.33578/jpfkip.v8i1.7119

ISSN : 2303-1514 | E-ISSN : 2598-5949

https://primary.ejournal.unri.ac.id/index.php/JPFKIP

Tabel. 3 Paired Samples Test

\begin{tabular}{|c|c|c|c|c|}
\hline \multicolumn{5}{|c|}{ Paired Samples Correlations } \\
\hline & & $\mathrm{N}$ & Correlation & Sig. \\
\hline $\begin{array}{c}\text { Pair } \\
1\end{array}$ & $\begin{array}{c}\text { sebelum \& } \\
\text { sesudah }\end{array}$ & 13 & .353 & .237 \\
\hline
\end{tabular}

Tabel. 4 Paired Samples Test

\begin{tabular}{|c|c|c|c|c|c|c|c|c|c|}
\hline \multicolumn{10}{|c|}{ Paired Samples Test } \\
\hline & & \multicolumn{5}{|c|}{ Paired Differences } & \multirow[t]{3}{*}{$\mathrm{t}$} & \multirow[t]{3}{*}{$\mathrm{df}$} & \multirow{3}{*}{$\begin{array}{c}\text { Sig. } \\
(2- \\
\text { tailed) }\end{array}$} \\
\hline & & \multirow[t]{2}{*}{ Mean } & \multirow[t]{2}{*}{$\begin{array}{c}\text { Std. } \\
\text { Deviation }\end{array}$} & \multirow{2}{*}{$\begin{array}{c}\text { Std. } \\
\text { Error } \\
\text { Mean }\end{array}$} & \multicolumn{2}{|c|}{$\begin{array}{l}95 \% \text { Confidence Interval } \\
\text { of the Difference }\end{array}$} & & & \\
\hline & & & & & Lower & Upper & & & \\
\hline Pair 1 & $\begin{array}{l}\text { sebelum - } \\
\text { sesudah }\end{array}$ & $\begin{array}{c}- \\
19.89615\end{array}$ & 7.36692 & 2.04322 & -24.34794 & $\begin{array}{c}- \\
15.44437\end{array}$ & $\begin{array}{c}- \\
9.738\end{array}$ & 12 & .000 \\
\hline
\end{tabular}

Berdasarkan hasil analisis melalui perbandingan skor sebelum dan sesudah tindakan pembelajaran menggunakan model Student Team Achievement Division (STAD), model ini dapat meningkatkan hasil belajar IPS Siswa SD mulai dari peningkatan terendah $6.9 \%$ sampai yang tertinggi $56.6 \%$ dengan rata-rata peningkatan sebesar $34.01 \%$.

Berdasarkan hasil Output Paired-Sample T Test pada tabel 2 menunjukkan bahwa pembelajaran IPS dengan menggunakan model Student Team Achievement Devision (STAD) mampu meningkatkan hasil belajar IPS Siswa SD dari nilai rata-rata 60.2292 menjadi 80.1254. Tabel 3 menunjukkan bahwa terdapat korelasi antara nilai rata-rata hasil belajar IPS siswa sebelum pembelajaran menggunakan model Student Team Achievement Devision (STAD) dan sesudah pembelajaran menggunakan model Student Team Achievement Devision (STAD). Hal ini ditunjukkan oleh nilai Correlation pada tabel 3 sebesar 0.353 dengan tingkat korelasi lemah.

Hasil uji hipotesis dengan $\mathrm{Ho}=$ tidak terdapat perbedaan yang signifikan hasil belajar IPS siswa sebelum dan sesudah pembelajaran menggunakan model Student Team Achievement Devision (STAD) dan $\mathrm{H} 1=$ terdapat perbedaan yang signifikan hasil belajar IPS siswa sebelum dan sesudah pembelajaran menggunakan model Student Team Achievement Devision (STAD). Berdasarkan tabel 4 menunjukkan bahwa nilai Sig. (2-tailed) $(0.000)<\alpha(0.05)$ dan

$\mathrm{t}_{\text {hitung }}=-9.738<\mathrm{t}_{\text {tabel }}=2.20099$ sehingga Ho di tolak. Jadi dapat disimpulkan bahwa terdapat perbeaan antara hasil belajar IPS siswa SD sebelum pembelajaran menggunakan model Student Team Achievement Devision (STAD) dan sesudah pembelajaran menggunakan model Student Team Achievement Devision (STAD).

Berdasarkan hasil-hasil penelitian diatas, dapat dilihat bahwa hasil penelitian peningkatan hasil belajar IPS siswa SD yang telah dilakukan memiliki presentase yang berbeda-beda. Perbedaan hasil penelitian yang diperoleh disebabkan oleh beberapa faktor baik faktor internal maupun eksternal. Faktor internal misalnya bakat, minat, kondisi siswa saat pengambilan data penelitian, dan intelegensi. Faktor eksternal misalnya kondisi kelas, lingkungan sekolah dan masyarakat. Selain itu, proses pembelajaran yang dilakukan oleh guru walaupun menggunakan jenis model pembelajaran yang sama, ada kemungkinan penerapan dalam pembelajaranpun berbeda-beda juga dapat mempengaruhi peningkatan hasil belajar IPS siswa SD. Misalnya guru menambahkan dengan bantuan media pembelajaran lain. 


\section{SIMPULAN DAN REKOMENDASI}

Berdasarkan hasil analisis model pembelajaran Student Team Achievement Devision (STAD) efektif digunakan untuk meningkatkan hasil belajar IPS siswa SD mulai dari yang terendah $6,9 \%$ sampai yang tertinggi 56,6\% dengan rata-rata peningkatan sebesar $34,01 \%$.

\section{DAFTAR PUSTAKA}

B. Achmad, S. (2014). Penggunaan Model Pembelajaran Kooperatif Tipe Student Team Achievement Devision (STAD) untuk Meningkatkan Hasil Belajar Siswa Kelas V SDN Kedungrejo, Waru-Sidoarjo. Jurnal JPGSD. (Online). http://jurnalmahasiswa.unesa.ac.id/index.p hp/jurnal-penelitian-

pgsd/article/view/10578 (diakses pada 6 Maret 2019)

Deswita, dkk. Implementation of Cooperative Learning Model Student Team Achievement Division Can Improve Learning Outcomes IPS Third Grade Students of SD Negeri 9 Duri Barat Kecamatan Mandau Tahun Ajaran 2015/2016. Jurnal Unri. https://media.neliti.com/media/publi cations/186513-ID-none.pdf (diakses pada 7 Maret 2019)

Dlita, H., dkk. (2016). Penerapan Model Pembelajaran Kooperatif Tipe STAD untuk Meningkatkan Hasil Belajar IPS Siswa Kelas IV SD Negeri 008 Talang Perigi Kecamatan Rakit Kulim Kabupaten Indragiri Hulu. Jurnal Unri. (Online). https://media.neliti.com/media/publications 1202242-penerapan-model-pembelajarankooperatif.pdf (diakses pada 7 Maret 2019).

Gusniar. (2014). Penerapan Model Pembelajaran Kooperatif Tipe Student Teams Achievment Division (STAD) Dalam Meningkatkan Hasil Belajar Siswa Pada Mata Pelajaran IPS Kelas IV SDN No. 2 Ogoamas II. Jurnal Kreatif Tadulako. (Online).

http://jurnal.untad.ac.id/jurnal/index.php/J
Saran untuk penelitian selanjutnya agar dapat mengikutsertakan lebih banyak artikel dan hasil skripsi lagi. Hal ini bertujuan agar data yang diperoleh lebih banyak, lebih luas dan dapat dilihat lebih dalam tentang hasil penelitiannya.

KTO/search/search (diakses 15 Maret 2019).

Jatimah. (2016). Peningkatan Aktivitas dan Hasil Belajar IPS Melalui Pembelajaran Kooperatif Tipe STAD Variasi Permainan Nagawan Pada Siswa Kelas V SD Negeri Perumnas oleh Jatimah. Jurnal Kreatif Tadulako. (Online). http://jurnal.untad.ac.id/jurnal/index.php/J KTO/search/search (diakses 5 Maret 2019)

Kristin, F. (2016). Efektivitas Model Pembelajaran Kooperatif Tipe STAD Ditinjau dari Hasil Belajar IPS Siswa Kelas 4 SD. Jurnal Scholaria. (Online). http://ejournal.uksw.edu/scholaria/article/v iew/230 (diakses 5 Maret 2019).

N. Lazim. (2017). Penerapan Model Pembelajaran Kooperatif Tipe Student Team Achievement Devision (STAD) untuk Meningkatkan Hasil Belajar IPS Siswa Kelas V SD Negeri 35 Pekanbaru. Jurnal Primary PGSD FKIP UNRI. https://ejournal.unri.ac.id/index.php/JPFKI P/article/view/4544 (diakses pada 7 Maret 2019).

Nugroho, O. W. D. (2014). Pengaruh Penerapan Model Pembelajaran Kooperatif Tipe STAD Terhadap Peningkatan Prestasi Belajar Mata Pelajaran IPS Pada Siswa Kelas V SD N Karang Duren. Skripsi tidak dipublikasikan. Fakultas Ilmu Pendidikan, Universitas Negeri Yogyakarta. Yogyakarta.

Puspitasari, W. D. (2018). Implementasi Model Pembelajaran Kooperative Tipe Student Team Achievement Divisions dalam Meningkatkan Hasil Belajar IPS Sumiyati, Elfa. 
https://journal.institutpendidikan.ac.id/inde x.php/mosharafa/article/view/mv5n2_15 (diakses 6 Maret 2016).

Rahmad. (2016). Kedudukan Ilmu Pengetahuan Sosial (IPS) pada Sekolah Dasar. Jurnal Muallimuna Madrasah Ibtidaiyah. (Online). $\quad$ https://ojs.uniskabjm.ac.id/index.php/jurnalmuallimuna/arti cle/view/742 (diakses 5 Maret 2019)

Rifai, M. (2014). Meningkatkan Prestasi Belajar Siswa dengan Pembelajaran IPS Siswa Kelas IV MIN Manisrejo Kota Madiun. Jurnal Educandum. (Online). http://ejournal.unipma.ac.id/index.php/PE/article/ view/315 (diakses pada 5 Maret 2019)

Rochmatin. (2014). Penerapan Model Pembelajaran Kooperatif Tipe STAD Meningkatkan Hasil Belajar Siswa dalam Pembelajaran IPS Kelas IV. Jurnal JPGSD. (Online).

http://jurnalmahasiswa.unesa.ac.id/index.p hp/jurnal-penelitianpgsd/article/view/12219 (diakses pada 6 Maret 2019)

Saten. (2015). Peningkatan Aktivitas dan Hasil Belajar Siswa dalam Pembelajaran IPS Tipe STAD Kelas V SD. Jurnal Pendidikan dan Pembelajaran Untan. (Online). $\quad$ http:// jurnal.untan.ac.id/index.php/jpdpb/article/v iew/10912 $+\& \mathrm{~cd}=1 \& \mathrm{hl}=\mathrm{en} \& \mathrm{ct}=\mathrm{clnk} \& \mathrm{gl}=\mathrm{id}$ (diakses pada 5 Maret 2019).

Sumiyati, E. (2017). Penggunaan Model Pembelajaran Interaktif Berbasis Aktivitas untuk Meningkatkan Prestasi Belajar Siswa Kelas VI pada Pelajaran PKn SD Negeri 09 Kabawetan. Jurnal PGSD Universitas Bengkulu. (Online). https://ejournal.unib.ac.id/index.php/pgsd/a rticle/view/3331 (diakses 5 Maret 2019).

Susanti, Y. (2017). Peningkatan Aktivitas dan Hasil Belajar Melalui Pembelajaran Kooperatif Tipe STAD. Jurnal Pendidikan: Teori, Penelitian dan Pengembangan. (Online).

http://journal.um.ac.id/index.php/jptpp/arti cle/view/9160 (diakses pada 7 Maret 2019)

Warti, E. (2016). Pengaruh Motivasi Belajar Siswa terhadap Hasil Belajar Matematika Siswa di SD Angkasa 10 Halim Perdana Kusuma Jakarta Timur. Jurnal Mosharafa Pendidikan Matematika STKIP Garut. (Online).

https://journal.institutpendidikan.ac.id/inde x.php/mosharafa/article/view/mv5n2 15 (diakses pada 5 Maret 2019)

Wijanarko, Y. (2017). Model Pembelajaran Make A Match Untuk Pembelajaran IPA Yang Menyenangkan. Jurnal Taman Cendikia, Vol. 01, No. 01. (Online). http://jurnal.ustjogja.ac.id/index.php/taman cendekia/article/view/1579 (diakses 6 Maret 2019).

Zahro, F., dkk. (2014). Pengaruh Model Pembelajaran Student Team Achievement Devision (STAD) dan Mind Mapping terhadap Hasil Belajar Siswa Kelas IV Sekolah Dasar. Jurnal Premiere Educandum. (Online). http://ejournal.unipma.ac.id/index.php/PE/article/ view/3021 (diakses 7 Maret 2019) 